\title{
MODEL COOPERATIVE LEARNING TIPE GROUP INVESTIGATION UNTUK MENINGKATKAN HASIL BELAJAR PADA MATA PELAJARAN PERAWATAN DAN PERBAIKAN SISTEM REFRIGERASI
}

\author{
Syamsuri Hasan, Maman Rakhman, Helga Ardiana \\ Jurusan Pendidikan Teknik Mesin FPTK UPI \\ Jl. Dr. Setiabudhi No. 207 Bandung 40154 \\ syamsuri_hasan@yahoo.com \\ mamanrakhman@yahoo.co.id \\ helga_ag@yahoo.co.id
}

\begin{abstract}
Abstrak: Penelitian ini bertujuan untuk mengetahui penerapan model group investigation dalam meningkatkan hasil belajar pada mata pelajaran perawatan dan perbaikan sistem refrigerasi. Penelitian ini dilakukan pada peserta didik di SMK Negeri 1 Cimahi Program Studi Teknik Pendinginan Kelas XI TP A Tahun Ajaran 2009/2010. Metode penelitian yang dipakai adalah penelitian tindakan kelas dengan menggunakan tiga siklus penelitian, disetiap siklusnya terdiri dari perencanaan, pelaksanaan, dan refleksi KBM. Hasil penelitian model pembelajaran ini meningkatkan hasil belajar peserta didik menggunakan perhitungan $\mathrm{N}$-Gain dengan jumlah prosentase terbesar berada pada siklus ke tiga sebesar 48,55 \%, dan kategori ini termasuk pada kategori sedang. Selain terjadi peningkatan pada hasil belajar, model pembelajaran group investigation ini membuat peserta didik menjadi lebih aktif dalam mengikuti kegiatan belajar mengajar.
\end{abstract}

Kata kunci: group investigation, hasil belajar, cooperative learning

\begin{abstract}
This study aims to investigate the application of group investigation model in improving learning outcomes in maintenance and repair of refrigeration systems subjects. The research was conducted to students in SMK Negeri (State Vocational School) 1 Cimahi joining Refrigeration Engineering Program Class XI TP A 2009/2010. The research method used here is classroom action research with three research cycles. Each cycle consists of learning-teaching activity planning, implementation and reflection. The study, using $\mathrm{N}$-Gain calculation, shows that this model improves the students' learning outcomes. The largest percentage is on the third cycle, which is $48.55 \%$, and falls into medium category. In addition to increasing learning outcome, the investigation group learning model also makes students more active in participating in the learning activities.
\end{abstract}

Keywords: group investigation, learning outcome, cooperative learning

\section{PENDAHULUAN}

Sejalan perkembangan dunia pendidikan yang semakin pesat menuntut lembaga pendidikan untuk lebih dapat menyesuaikan dengan perkembangan ilmu pengetahuan. Banyak perhatian khusus diarahkan kepada perkembangan dan kemajuan pendidikan guna meningkatkan mutu dan kualitas pendidikan. Oleh karena itu, model pembelajaran yang efektif dan efisien dalam mencetak peserta didik yang lebih berkualitas diperlukan. Banyak dikembangkan model pembelajaran, salah satunya adalah model pembelajaran kooperatif group investigaton (GI). Menurut Winataputra (1992:39), model GI atau investigasi kelompok telah digunakan dalam berbagai situasi dan berbagai bidang studi dan berbagai tingkat usia. Pada dasarnya model ini dirancang untuk membimbing para peserta didik mendefinisikan masalah, mengeksplorasi berbagai cakrawala mengenai masalah itu, mengumpulkan data yang relevan, mengembangkan dan menguji hipotesis. 
Kurikulum Tingkat Satuan Pembelajaran (KTSP) menuntut kegiatan pembelajaran di dalam kelas berlandaskan pendekatan pada murid atau student centered approach. Pada kenyataannya masih belum diterapkan oleh semua guru dalam kegiatan pembelajaran. Sehingga masih kurangnya peran aktif peserta didik dalam kegiatan pembelajaran. Hal ini terlihat saat kegiatan pembelajaran menjadi kurang adanya komunikasi dua arah antara guru dan peserta didik. Sehingga kondisi belajar menjadi tidak menarik, peserta didik cepat jenuh dan menjadi tidak konsentrasi dalam belajar di kelas teori. Berdasar permasalahan ini perlu kiranya guru mempergunakan alternatif model pembelajaran untuk student centered approach, salah satunya adalah menerapkan model pembelajaran kooperatif tipe group investigation.

Tujuan penelitian ini adalah untuk mengetahui penerapan model pembelajaran kooperatif tipe group investigation. Apakah pembelajaran tersebut membuat pembelajaran menjadi lebih menarik dan cocok digunakan pada kurikulum KTSP. Tujuan penelitian ini juga untuk mengetahui keaktifan peserta didik dalam proses pembelajaran dengan model kooperatif pada mata pelajaran Perawatan dan Perbaikan Sistem Refrigerasi. Selain itu, untuk mengetahui peningkatan nilai hasil belajar perserta didik setelah menerapkan model pembelajaran kooperatif tipe group investigation.

Pembelajaran kooperatif merupakan suatu model pembelajaran yang menekankan aktifitas peserta didik dalam kelompok kecil sehingga peserta didik dapat saling bekerja sama untuk mencapai tujuan pembelajaran. Peserta didik dalam kelompok kooperatif belajar berdiskusi, saling membantu, dan mengajak satu sama lain untuk mengatasi masalah belajar. Pembelajaran kooperatif mengkondisikan peserta didik untuk aktif dan saling memberi dukungan dalam kerja kelompok untuk menuntaskan masalah dalam belajar. Pembelajaran kooperatif merupakan salah satu model pembelajaran yang mengutamakan kebersamaan kelompok.

Pembelajaran kooperatif merupakan pembelajaran yang mengutamakan kerja sama antar peserta didik untuk mencapai tujuan pembelajaran. Kesuksesan dari sebuah kelompok bergantung pada kesuksesan masing-masing anggota kelompok. Menurut teori konstruktivis, tugas guru (pendidik) adalah memfasilitasi agar proses pembentukan (konstruksi) pengetahuan pada diri sendiri tiap-tiap peserta didik terjadi secara optimal. Dalam pembelajarannya peserta didik diharapkan saling membantu, berdiskusi, berdebat, atau saling menilai pengetahuan dan pemahaman satu sama lain. Menurut Sugandi (2002), karakteristik model pembelajaran kooperatif tipe group investigation. Berdasarkan definisi tersebut karakteristik model pembelajaran kooperatif, sebagai berikut:

1. Siswa belajar dalam kelompok. 
2. Siswa memiliki rasa saling ketergantungan.

3. Siswa belajar berinteraksi secara kerja sama.

4. Siswa dilatih untuk bertanggung jawab terhadap tugas.

Siswa memiliki keterampilan komunikasi interpersonal. Ciri-ciri tersebut dapat memberikan dampak positif kepada peserta didik antara lain: membangun sikap belajar kelompok/bersosialisasi, membangun kemampuan bekerjasama, melatih kecakapan berkomunikasi, melatih keterlibatan emosi peserta didik, mengembangkan rasa percaya diri dalam belajar, meningkatkan prestasi akademiknya secara individu dan kelompok, meningkatkan motivasi belajar dan memperoleh kepuasan belajar. Tinggi rendahnya tingkat keberhasilan model pembelajaran kooperatif di atas, bergantung pada aspek: interdependensi ganjara, interdependensi tugas, tanggung jawab atau akuntabilitas individual, struktur yang dipaksakan oleh guru, ada atau tidak adanya kompetisi kelompok.

Model pembelajaran kooperatif mempunyai banyak macam jenisnya, salah satu dan menjadi bahan penelitian penerapan model pembelajaran kooperatif tipe group investigation. Model ini memiliki akar filosofis, etis dan psikologi penulisan sejak awal tahun abad ini. Penulis yang paling terkenal diantara tokoh terkemuka dari orientasi pendidikan adalah John Dewey. Pandangan Dewey terhadap kooperatif di dalam kelas sebagai sebuah prasyarat untuk bisa menghadapi berbagai masalah kehidupan yang kompleks dalam masyarakat demokrasi. Kelas adalah sebuah kreatifitas kooperatif di mana guru dan murid membangun proses pembelajaran yang didasarkan pada perencanaan mutual dari berbagai pengalaman, kapasitas, dan keutuhan masing-masing. (Slavin 2009: 214).

Peserta didik di dalam kelas belajar untuk berkomunikasi untuk mengeluarkan pendapat baik secara lisan atau dengan tulisan, seperti halnya dalam kehidupan bermasyarakat secara luas. Kelas merupakan prototipe kehidupan masyarakat sekitar, dimana akan terjadi banyak perbedaan pendapat, pola pikir dan tingkah laku. Peserta didik dan guru yang merupakan bagian dari prototipe masyarakat tersebut di tuntut untuk bisa memerankan peran mereka masing-masing untuk mencapai suatu tujuan. Guru selaku orang yang lebih berpengalaman baik dalam hal bermasyarakat ataupun dalam segi ilmu pengetahuan harus bisa mengarahkan dan memfasilitasi peserta didik untuk bisa meningkatkan kecerdasan intelektual, kecerdasan emosional dan kecerdasan spiritual. Sedangkan peserta didik adalah pihak yang belajar harus berpartisipasi aktif dalam segala aspek kehidupan sekolah, memuat keputusan yang menentukan tujuan terhadap apa yang mereka kerjakan. Kelompok dijadikan sarana sosial dalam proses ini. Rencanaan kelompok adalah satu metode untuk mendorong ketertiban maksimal para peserta didik. 
Belajar merupakan hal yang sangat penting bagi kehidupan manusia. Dikatakan demikian, karena di setiap kehidupan terjadi proses belajar, baik secara disengaja maupun tidak, disadari maupun tidak disadari. Proses belajar ini akan diperoleh suatu hasil yang pada umumnya disebut hasil belajar, tetapi agar memperoleh hasil yang optimal maka proses belajar harus dilakukan dengan sadar dan sengaja serta terorganisir dengan baik. Berikut ini beberapa pengertian tentang belajar menurut Oemar Hamalik (1990:21), menjelaskan bahwa "belajar merupakan bentuk pertumbuhan atau perubahan dalam diri seseorang yang dinyatakan dalam cara bertingkah laku yang baru berkat pengalaman dan latihan. Menurut pandangan B. F. Skinner (1958), "belajar merupakan suatu proses atau penyesuaian tingkah laku yang berlangsung secara progresif. Pengertian belajar ialah suatu perubahan dalam kemungkinan atau peluang terjadinya respons". Slameto (2005:2), menjelaskan bahwa belajar ialah suatu proses usaha yang dilakukan seseorang untuk memperoleh suatu perubahan tingkah laku yang baru secara keseluruhan. Sebagai hasil dari pengalamannya sendiri dalam interaksi dengan lingkungannya. Sadiman A.M (2006:21), menyatakan bahwa "belajar itu sebagai rangkaian kegiatan jiwa raga, psiko-pisik untuk menuju perkembangan pribadi manusia seutuhnya, yang berarti menyangkut unsur cipta, rasa, dan karsa ranah kognitif, afektif dan psikomotorik

Hasil belajar ini dilengkapi dengan serangkaian pengalaman yang baik dan lambat laun menjadi kepribadian dengan kecepatan yang berbeda. Hasil belajar yang telah dicapai ini bersifat kompleks dan dapat berubah, jadi tidak bersifat sederhana atau statis. Hasil belajar juga didefinisikan sebagai hasil yang diperoleh setelah seseorang mengikuti pendidikan yang dapat ditentukan dengan memberi tes pada hasil pendidikan itu. Dengan demikian, hasil belajar merupakan perbedaan tingkah laku yang positif antara setelah belajar dengan sebelum belajar yang berupa penampilan yang dapat diamati serta kecenderungan perilaku yang tidak dapat diamati atau diukur. Hasil belajar yang telah dicapai ini bersifat kompleks dan dapat berubah-ubah, jadi tidak bersifat sederhana atau statis (Oemar Hamalik, 1990: 65). Menurut teori Benyamin S. Bloom yang dikenal dengan teori taksonomi Bloom, hasil belajar dapat dibagi ke dalam tiga aspek yaitu aspek kognitif, aspek afektif dan aspek psikomotor.

Evaluasi hasil belajar adalah keseluruhan kegiatan pengukuran (pengumpulan data dan informasi), pengolahan, penafsiran dan pertimbangan. Untuk membuat keputusan tentang tingkat hasil belajar yang dicapai oleh peserta didik setelah melakukan kegiatan belajar dalam upaya mencapai tujuan pembelajaran yang telah ditetapkan. Hasil belajar menunjuk pada prestasi belajar, sedangkan prestasi belajar merupakan indikator adanya peningkatan belajar dan derajat perubahan tingkah laku peserta didik. 


\section{METODE}

Metode penelitian yang digunakan dalam penelitian ini yaitu metode Penelitian Tindakan Kelas (PTK). PTK dimulai dengan adanya masalah yang dirasakan sendiri oleh guru dalam pembelajaran. Masalah tersebut dapat berupa segala sesuatu yang berhubungan dengan proses atau hasil belajar peserta didik yang tidak sesuai dengan harapan guru atau halhal lain yang berkaitan dengan model pembelajaran dan perilaku belajar peserta didik. Tahapan PTK dimulai dengan menemukan masalah dilanjutkan dengan menganalisis dan merumuskan masalah, kemudian merencanakan PTK dalam bentuk tindakan perbaikan, mengamati, dan melakukan refleksi.

Rancangan penelitian tindakan kelas pada prinsipnya peneliti sendirilah yang menjadi instrumen utama (human instrument) yang terjun ke lapangan serta berusaha mengumpulkan sendiri informasi yang diperlukan. Penempatan peneliti sebagai instrumen berpijak pada asumsi bahwa hanya manusialah yang mampu memahami, memberikan makna terhadap interaksi antar manusia, gerak muka, menyelami perasaan dan nilai yang terkandung dalam ucapan atau perbuatan yang mereka lakukan. Penentuan teknik pengumpulan data disesuaikan dengan permasalahan yang ada dalam penelitian. Teknik pengumpulan data yang digunakan dalam penelitian ini adalah pedoman observasi dan tes.

\section{HASIL PENELITIAN}

Hasil penelitian menunjukkan bahwa peningkatan hasil peserta didik selama tiga siklus dengan menggunakan model pembelajaran cooperative learning tipe group investigation. Peningkatan yang paling besar terjadi pada siklus kedua dengan prosentase sebesar 15,02\% dibandingkan dengan siklus ketiga kenaikannya sebesar 4\%, meskipun begitu jika dilihat secara keseluruhan kegiatan belajar mengajar dengan menggunakan model pembelajaran cooperative learning tipe group investigation berdasarkan perhitungan $\mathrm{N}-$ Gain berada pada kategori sedang.

Meningkatnya hasil belajar peserta didik bukan terjadi secara cepat atau ajaib, akan tetapi meningkatnya hasil belajar peserta didik melalui suatu proses yang kontinu dan melibatkan beragam faktor, salah satu faktornya adalah tingkat keaktifan peserta didik sendiri dalam mengikuti kegiatan belajar mengajar.

Hasil penelitian dalam aktivitas peserta didik menunjukkan peningkatan terhadap aktivitas peserta didik selama mengikuti KBM pada tiap siklusnya, walaupun tidak mengalami peningkatan yang tinggi pada siklus ketiga terhadap siklus kedua, akan tetapi dari siklus pertama sebesar 55,4\% termasuk pada kategori rendah mengalami peningkatan sebesar $11,4 \%$, sedangkan pada siklus kedua dan ketiga termasuk kategori sedang dengan prosentase 
masing-masing sebesar $66,10 \%$ dan 73,33\%. Dengan demikian, aktivitas peserta didik selama mengikuti kegiatan belajar mengajar dengan menggunakan model pembelajaran group investigation mendapatkan respon yang cukup baik dari peserta didik.

Observasi keberhasilan model pembelajaran dilakukan dengan tujuan melihat sejauh mana tingkat keberhasilan model pembelajaran dalam hal ini adalah group investigation dapat meningkatkan hasil belajar dan keaktifan peserta didik.

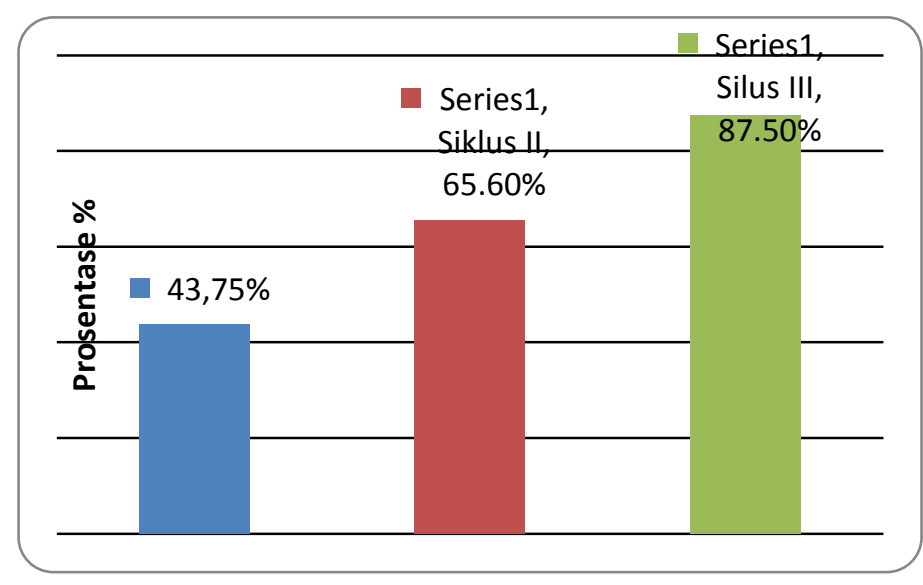

Gambar 1. Grafik Peningkat Keberhasilan Model Pembelajaran GI

\section{PEMBAHASAN}

Hasil belajar peserta didik selama kegiatan pembelajaran dengan penerapan model pembelajaran kooperatif tipe group investigation menunjukkan peningkatan. Peningkatan hasil belajar peserta didik juga diikuti dengan meningkatnya aktivitas positif peserta didik. Aktivitas tersebut antara lain: mendengarkan atau memperhatikan guru dengan seksama, menulis hal penting tentang materi pembelajaran, membaca dan mengerjakan tugas, saling kooperatif selama PBM, diskusi dalam memecahkan permasalahan, mempresentasikan hasil kerja kelompok, dan kesungguhan melaksanakan evaluasi dengan tertib. Dengan demikian, model pembelajaran group investigation ini bisa dipakai sebagai alternatif model pembelajaran yang sesuai dengan pendekatan kurikulum pendidikan di Indonesia yang sekarang yaitu student centered approach.

Penelitian ini pada dasarnya bertujuan untuk melihat sejauh mana peserta didik dapat meningkatkan hasil belajarnya dengan menggunakan model pembelajaran group investigation. Kegiatan pembelajaran pada siklus pertama menunjukan bahwa hasil belajar peserta didik tergolong kategori rendah, hal ini terjadi karena peneliti belum bisa mengkondisikan peserta didik di kelas, terutama pada kegiatan presentasi di kelas sehingga kurang kondusif. Ketika kegiatan belajar mengajar dengan menggunakan model pembelajaran group investigation, peneliti masih terlihat belum maksimal dalam penerapannya. Akibatnya 
masih adanya peserta didik yang belum memahami tentang materi ini, juga peneliti masih kurang memotivasi peserta didik dalam diskusi kelas.

Perubahan sikap dan tingkah laku peserta didik pada siklus pertama belum terlihat. Hal ini disebabkan oleh faktor masih banyaknya peserta didik yang belum aktif terutama di dalam kegiatan diskusi. Karena masih kurangnya rasa percaya diri dari peserta didik untuk bertanya, maka apabila ada yang tidak dimengerti maupun untuk memberikan tanggapan atau pertanyaan pada saat kegiatan presentasi. Akibat dari hal tersebut karakteristik model pembelajaran kooperatif yang salah satu poinnya menekankan rasa ketergantungan terhadap kelompok dan tugas yang telah di dapat oleh anggota kelompok tidak berjalan. Kondisi seperti ini berdampak pada tingkat kompetisi antar kelompok saat diskusi masih rendah. Mereka cenderung hanya menjadi penonton saat kelompok lain mempresentasikan hasil investigasinya, sehingga membuat kegiatan diskusi menjadi kurang menarik.

Kegiatan pembelajaran pada siklus kedua menunjukan bahwa hasil belajar peserta didik mulai mengalami peningkatan. Hal ini ditunjukan dengan persentase $N-$ Gain termasuk pada kategori sedang. Peningkatan persentase ini terjadi karena peneliti telah belajar dari pengalaman ketika di siklus pertama, dan peserta didik mulai memperlihatkan perubahan sikap dan tingkah laku dalam bertindak dalam kegiatan belajar mengajar. Kondisi seperti ini sesuai dengan yang diharapkan para ahli pendidikan yang mendefinisikan belajar adalah suatu proses perubahan pola fikir dan tingkah laku individu yang baru dan lebih baik dari sebelumnya. Berkat pengalaman dan latihan tersebut, siswa mengalami kecepatan perubahan pada tiap individu, walaupun hasilnya berbeda-beda.

Karakteristik model pembelajaran kooperatif pun mulai nampak, hal ini diperlihatkan dengan pesetra didik mulai memperlihatkan rasa tanggung jawab terhadap tugas yang diembannya. Peserta didik mulai bekerja sama dalam menyelesaikan tugas yang dibebankan pada kelompoknya. Walaupun belum terjadi pemerataan akan tetapi peningkatan ini suatu langkah awal keberhasilan dalam kegiatan belajar mengajar.

Karakteristik model pembelajaran kooperatif sebagai acuan berhasil atau tidaknya model pembelajaran group investigation menunjukan hasil yang memuaskan. Peserta didik yang biasanya pasif dalam kegiatan pembelajaran, menjadi lebih aktif dan lebih berani dalam mengajukan atau menjawab pertanyaan baik dari guru maupun teman-temannya. Peserta didik dapat meningkatkan kerja sama di dalam kelompok selama kegiatan PBM, berpartisipasi dalam kegiatan diskusi untuk memecahkan permasalahan, bertanggung jawab melaksanakan tugas praktikum yang diberikannya, mempresentasikan hasil kerja kelompok, serta kesungguhan melaksanakan tes evaluasi dengan tertib. 


\section{KESIMPULAN}

Pembelajaran dengan menggunakan model cooperative learning tipe group investigation membuat kegiatan belajar mengajar menjadi lebih menarik dan sesuai dengan kurikulum KTSP yang lebih mengutamakan pendekatan peserta didik sebagai pusat pembelajaran atau student centered approach. Akivitas belajar peserta didik pada proses pembelajaran perawatan dan perbaikan sistem refrigerasi dengan model cooperative learning tipe group investigation, menuntut peserta didik untuk lebih aktif dengan pengembangan kegiatan pembelajaran, seperti harus memahami suatu konsep atau materi dan mereka bertanggung jawab atas materi tersebut untuk disampaikan kepada teman-temannya di kelompok. Model cooperative learning tipe group investigation dapat meningkatkan hasil belajar peserta didik dan kemampuannya memahami materi mata pelajaran perawatan dan perbaikan sistem refrigerasi.

\section{DAFTAR PUSTAKA}

Budi. (2008). Teori Belajar (Inisiasi PKN). [Online]. Tersedia: http://pdf-searchengine.com/UNIT\%201-html-budimeeong.files.wordpress.com/2005/05/ inisiasi_pkn_1.html.[24Juli 2009].

Krismanto. (2008). Karakteristik model pembelajaran group investigation (GI). [Online]. Tersedia: http://www.wordpress.com/pembelajaran-kooperatif/ karakteristik-modelpembelajaran-group-investigation.html

Muhfida. (2009). Metode pembelajaran kooperatif. [Online]. Tersedia: http://www.muhfida.com/modelpembelajaran.html. [23 Juli 2009].

Rustam, dan Mundilarto. (2004) Penelitian Tindakan Kelas. [Online]. www.depdiknas.go.id. [19 September 2008].

Sardiman, A.M. (2006) Interaksi dan Motivasi Belajar. Jakarta: PT.

Raja Grafindo Persada.

Slavin, Robert E. (2009). Cooperative Learning Teori, Riset dan Praktek. Bandung: Nusa Media [Penerjemah: Lita].

Sudrajat, Akhmad. (2009). Pengertian-pendekatan-strategi-metode-teknik-taktik-dan-modelpembelajaran. [Online]. Tersedia: www.psbpsma.org/content/blog/modelpembelajaran/. [23 Juli 2009].

Suherman, A. (2008). Perencanaan Pembelajaran Vokasional untuk Pendidikan dan Latihan Profesi Guru (PLPG). UPI Bandung: tidak diterbitkan.

Sugiono. (2008). Metode Penelitian Pendidikan Pendekatan Kualitatif, Kuantitatif, R\&D (Cetakan keempat). Bandung: CV. Alfabeta.

Sumarmo, U. et al. (2006). Metacognitive Approch to Improve Mathematics Skills of High School Students. International Journal of Education. 1 (1), 68-85. 